\title{
Influence of Crushed Coarse Aggregates on Properties of Concrete
}

\author{
I. B. Muhit ${ }^{1, *}$, S. Haque ${ }^{1}$, Md. Rabiul Alam² \\ ${ }^{1}$ Department of Civil Engineering, Chittagong University of Engineering \& Technology, Chittagong, Bangladesh \\ ${ }^{2}$ Professor, Department of Civil Engineering, Chittagong University of Engineering \& Technology, Chittagong-4349, Bangladesh \\ *Corresponding author: imrose_cuet@live.com
}

Received May 30, 2013; Revised July 12, 2013; Accepted July 16, 2013

\begin{abstract}
Both coarse aggregates and fine aggregates are the main constituents of concrete because they not only give the body to the concrete, it also have a significant effect on the fresh concrete based on aggregate's shape, size, texture, grading and crushing type. Moreover it is proved that aggregate's types has the severe effect on physicmechanical properties of concrete as aggregate covered almost 70 to 80 percent of the total volume of concrete. This paper investigates the effects on properties of concrete due to types of crushed aggregates alone. To observe the effects of crushed aggregates sharply, all other components like water cement ratio kept constant for each type and two types of crushed aggregates were used. 'Impact Crushed' and 'Vertically Shafted' aggregates type have been used to prepare five different groups of concrete blocks and these five groups have different water-cement ( $w / c)$ ratio. Source of these two aggregates, density and water absorption also kept constant to identify the effects on properties of concrete only for crushing type. Finally after 1 week and after 4 weeks slump values (consistency of the concrete) and compressive strength were measured without mixing any admixture or superplasticiser to the concrete. Compressive strength difference for all groups at 1 week and 4 weeks also analysed at the end of the study.
\end{abstract}

Keywords: aggregates, properties of concrete, type of aggregates, water cement ratio, water absorption

Cite This Article: Muhit, I. B., S. Haque, and Md. Rabiul Alam, "Influence of Crushed Coarse Aggregates on Properties of Concrete." American Journal of Civil Engineering and Architecture 1, no. 5 (2013): 103-106. doi: 10.12691/ajcea-1-5-3.

\section{Introduction}

Concrete is a composite material consists of filler and binding material where the filler materials are fine or coarse aggregate and binding materials are cement paste. At the earlier stage of concrete development, it was believed that aggregates were chemically inert and held together by cement. But modern technology proves that aggregates exhibits chemical bond at the interface of aggregate and paste. Aggregate is such important matter in concrete that maximum properties and workability of concrete are directly changed with the properties of aggregates. Density of concrete is determined by the aggregate density as well as soft with porous concrete produce weak concrete with lower wear resistance. That's why the overall or mechanical properties of concrete depends on the certain properties of aggregates like source of aggregates, normal or light or heavy weight aggregate, size of aggregate, shape of aggregate, crushing type of aggregates, angularity index, surface texture, modulus of elasticity, bulk density, specific gravity, absorption and moisture content, bulking of aggregates, cleanliness, soundness of aggregates, thermal properties and grading of aggregates. Moreover, Interfacial Transition Zone (contact surface between aggregate and cement paste) plays an important role in strength and durability of concrete.

But aggregates should be clean and free from impurities which are likely to interfere with the process of hydration, prevention of effective bond between the aggregates and matrix and it reduces the durability of concrete. Sometimes excessive silt and clay contained in the fine or coarse aggregate may result in increase shrinkage or increased permeability in addition to poor bond characteristics [1]. Adherence reducing material like silt and clay must not be covered by aggregates surface and both aggregates and surface geometry must not allow any spaces which are being arisen from strike of cement particles [2]. This situation is defined as 'wall effects'. To avoid such kind of spaces aggregates shape is a key fact and if aggregates voids are minimised, the amount of cement paste required to fill those voids also minimised maintaining workability and strength. It is difficult to really measure the shape of irregular body like concrete aggregate which are derived from rocks. Not only have the characteristics of the parent rock but also the type of crusher used in crushing, influence the shape of aggregates. Research shows that, there is a relationship between the voids of aggregates and shape, texture and grading of aggregates [3]. In rounded, cubical and well graded particles exhibits lower void content than flaky, elongated and angular aggregates. Roundness and 
angularity are the important characteristics of aggregates. Roundness is the outline of the particle and it may be measured in terms of convexity where angularity indicates the sharpness of the edges and corners [4,5]. However, flaky and elongated particles can produce harsh mixtures and seriously effect in workability. An excess of poorly shaped particles could reduce the strength of concrete through the increase of water demand. In addition, flat particles can be oriented in such a way that they could impair the strength and the durability of concrete [6,7]. In concrete pavements, flat particles near the surface inhibit bleed water from entering mortar above particle, thus contributing to the deterioration of the surface [8]. So from literature it is clear that crushing type of aggregates definitely has effects on properties of concrete because crushing type of aggregate can change and control the shape factor directly. To identify the effects on mechanical properties of concrete (slump value and compressive strength) of Impact Crushed and Vertically Shafted aggregates this study was conveyed.

\section{Experimental Procedure and Approach}

To evaluate the effects on properties of concrete due to different crushing of aggregates same cement and quality of water was used. Fine aggregate (sand), impact crushed coarse aggregate (A-1) and vertically shafted coarse aggregate (A-2) properties were evaluated through lab testing. Source of aggregates, density and porosity (water absorption) of A1 and A2 coarse aggregates were kept constant. From lab testing it was found that, the density of fine aggregates, impact crushed (A-1) coarse aggregates and vertically shafted (A-2) coarse aggregates were 2.79 $\mathrm{g} / \mathrm{cm}^{3}, 2.70 \mathrm{~g} / \mathrm{cm}^{3}$ and $2.70 \mathrm{~g} / \mathrm{cm}^{3}$ respectively. Water absorption percentage was determined by measuring the increase in weight of an oven dry sample when immersed in water for 24 hours. Water absorption percentage of fine aggregates, impact crushed (A-1) coarse aggregates and vertically shafted (A-2) coarse aggregates were $0.9 \%$, $1.4 \%$ and $1.4 \%$ respectively. And weight per unit of volume for fine aggregates, impact crushed (A-1) coarse aggregates and vertically shafted (A-2) coarse aggregates were $1650 \mathrm{~kg} / \mathrm{m}^{3}, 1420 \mathrm{~kg} / \mathrm{m}^{3}$ and $1375 \mathrm{~kg} / \mathrm{m}^{3}$ respectively. Impact crushers break materials according to two principle of breaking and it has high material capacities [9]. That's why impact crushers use primary as well as secondary steps and supplies more finer material then jaw crushers in initial step. Most importantly, here no secondary crusher needed and can supply material in required grade and thickness. Therefore, impact crushers have high performance, low operation and maintenance cost as well as easy repairing and handling. On the contrary, in case of application secondary as well as tertiary processes are followed by vertically shafted crushers [10]. The discharge particle size is relatively small; particle shape is cubic and exhibits good abrasion resistance.

Total 80 samples were prepared and among these 40 samples were tested for 1 weeks (7 days) and rest of the samples (40 samples) were tested for 4 weeks (28 days). The first 40 samples were categorized into 5 groups based on five different w/c ratios. Each set of group contains 8 samples where 4 samples for A-1 coarse aggregates and 4 samples were A-2 coarse aggregates with same w/c ratio for both. Rest 40 samples also consist of same pattern as like as first 40 samples. Slum value of concrete, compressive strength for 1 week and compressive strength for 4 weeks were tested for A-1 and A-2 coarse aggregates. Maintaining concrete testing standards the samples dimension were taken cubic as $150 \mathrm{~mm} \mathrm{x} 150 \mathrm{~mm} \mathrm{x}$ $150 \mathrm{~mm}$. The mixture properties are showed in Table 1.

For slump test which was conveyed to identify the consistency of the concrete, a typical mould of bottom diameter $20 \mathrm{~cm}$, top diameter $10 \mathrm{~cm}$ and height $30 \mathrm{~cm}$ was used. During compaction of concrete, compaction was conveyed by electric vibrator and special care was taken to avoid segregation. During curing period, the samples were stored in place free from vibration and in relatively moist air at a temperature ranges from $25^{\circ} \mathrm{C}$ to $27^{\circ} \mathrm{C}$. After 2 days mould was removed and marked with symbol to identify later and finally cured under clean fresh water. All the works done with maintaining various ASTM standards [11-23].

\begin{tabular}{|c|c|c|c|c|c|}
\hline $\begin{array}{c}\text { Tample 1. Sample properties details } \\
\begin{array}{c}\text { Group } \\
\text { No. }\end{array}\end{array}$ & $\begin{array}{c}\text { Cement } \\
(\mathrm{Kg})\end{array}$ & $\begin{array}{c}\text { Water } \\
(\mathrm{Kg})\end{array}$ & $\begin{array}{c}\text { Fine } \\
\text { Aggregate } \\
(\mathrm{Kg})\end{array}$ & $\begin{array}{c}\text { Coarse } \\
\text { Aggregate } \\
(\mathrm{Kg})\end{array}$ & $\begin{array}{c}\text { W/C } \\
\text { ratio }\end{array}$ \\
\hline $\begin{array}{c}\text { Group-I } \\
\text { Group- } \\
\text { II }\end{array}$ & 210 & 126 & 496 & 752 & 0.60 \\
\hline $\begin{array}{c}\text { Group- } \\
\text { III }\end{array}$ & 274 & 129 & 429 & 752 & 0.47 \\
\hline $\begin{array}{c}\text { Group- } \\
\text { IV }\end{array}$ & 311 & 131 & 390 & 752 & 0.42 \\
\hline $\begin{array}{c}\text { Group- } \\
\text { V }\end{array}$ & 350 & 133 & 349 & 752 & 0.38 \\
\hline
\end{tabular}

\section{Results and Discussions}

\subsection{Crushed Aggregate's Effects on Slumps of Concrete}

The Figure 1 depicts slum value of A-1 coarse aggregates for all five groups. For Impact Crushed (A-1) coarse aggregates slump values were evaluated for all five groups and it was evident from experiment that, there was a steady decrease in slump value with the decrease of w/c ratio. That means slump value of A-1 coarse aggregate was higher (145 mm) for Group-I and lower (92 mm) for Group-V. 


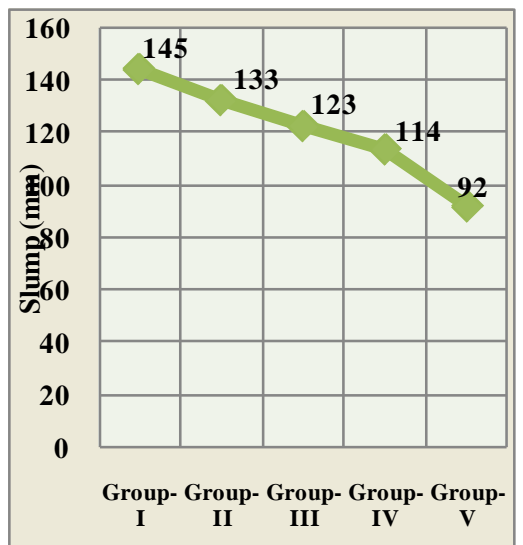

Figure 1. Slump value of concrete of A-1 coarse aggregates for five groups

The Figure 2 presents the slump value of A-2 coarse aggregate die all groups. For Vertically Shafted (A-2) coarse aggregates, slump values were also examined for all five groups and it was evident from investigation that, slump of concrete was decreases as like A-1 coarse aggregate with the decrease of w/c ratio. That means for A-2 coarse aggregates slump value was higher $(158 \mathrm{~mm})$ for Group-I and lower (103 mm) for Group-V.

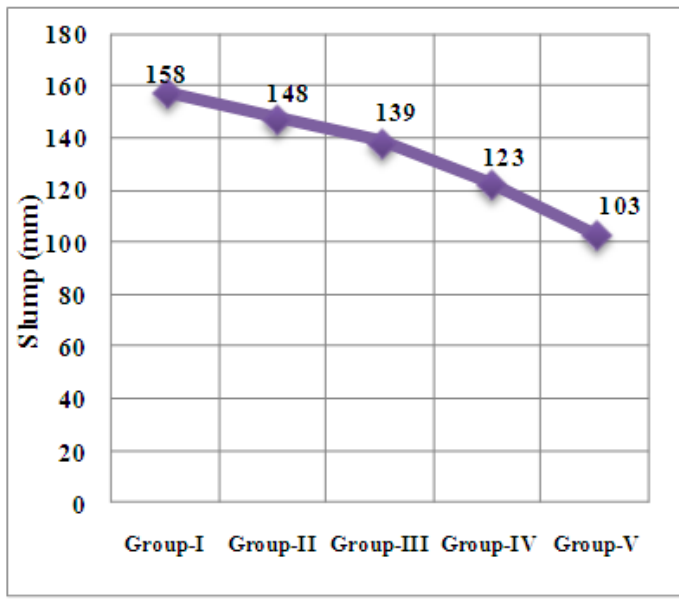

Figure 2. Slump value of concrete of A-2 coarse aggregates for five groups

\subsection{Crushed Aggregate's Effects on Compressive Strength of Concrete}

For both type of crushed coarse aggregates (A-1 \& A-2) there were effects on compressive strength of 1 weeks and 4 weeks and it has an upward trend with some fluctuations from Group-I to Group-V. Figure 3 depicts the compressive strength of both type aggregates for all 5 groups aged of 1 week.

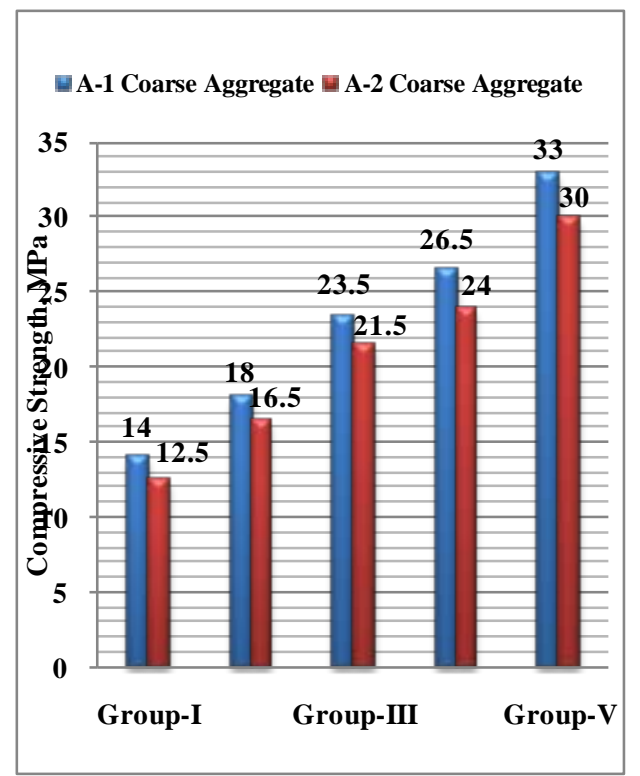

Figure 3. Compressive strength for A-1 and A-2 coarse aggregates at 1 week

From experiment it was observed that, A-1 coarse aggregates exhibited more compressive strength (for both 1 weeks and 4 weeks) than A-2 coarse aggregates. Compressive strength was increased moderately for both type crushed aggregates with the decrease of w/c ratio. For A-1 coarse aggregate, lower compressive strength (14 $\mathrm{MPa}$ ) was recorded for Group-I and higher compressive strength (33 MPa) was for Group-V at 1 weeks (7 days).

The Figure 4 illustrates the compressive strength of both types coarse aggregates for all five groups aged of 4 weeks. During this time, compressive strength of A-1 coarse aggregates ranges between $22 \mathrm{MPa}$ to $41.5 \mathrm{MPa}$ and compressive strength of A-2 coarse aggregates ranges between 19.5 $\mathrm{MPa}$ to $38.5 \mathrm{MPa}$. Highest compressive strength was recorded for 'A-1 with Group-V' series which had w/c ratio of 0.38 with impact crushed coarse aggregate. 


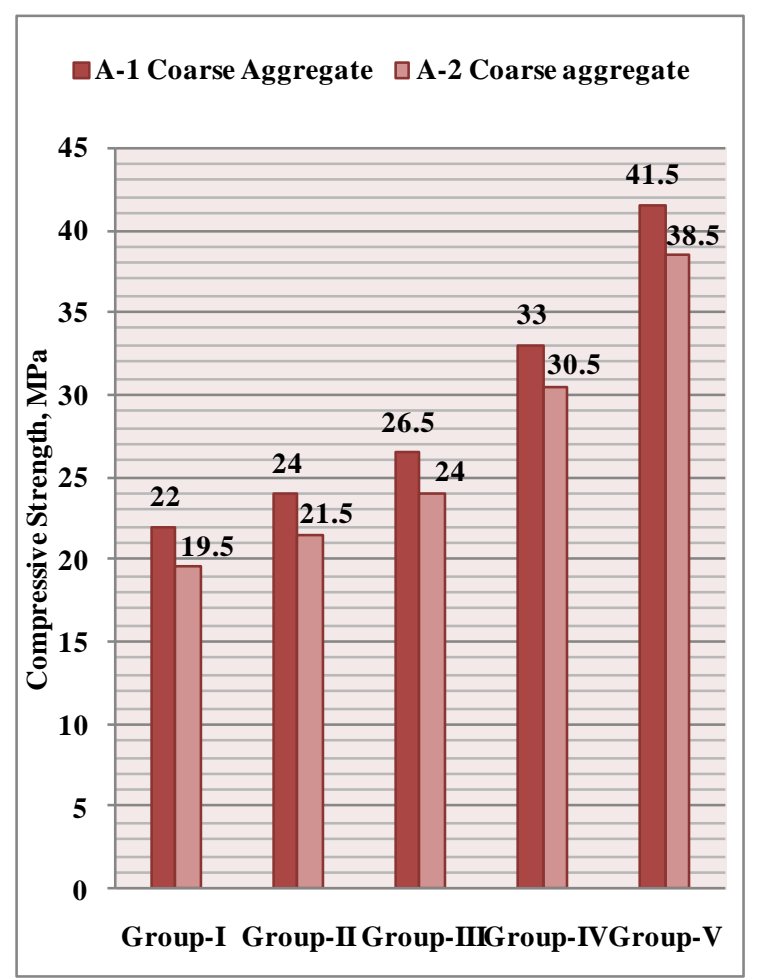

Figure 4. Compressive strength for A-1 and A-2 coarse aggregates at 4 weeks

\subsection{Comparison between A-1 and A-2 Coarse Aggregate}

From systematic and standardized investigation it is clear that, type of crushing aggregate has dramatic effects on properties of concrete. At 1 week and 4 weeks the strength fluctuation also obtained for five different groups. In all case, strength decreases in case of vertically shafted (A-2) coarse aggregates. At 1 week, for Group-I strength difference between $\mathrm{A}-1$ and $\mathrm{A}-2$ was $1.5 \mathrm{MPa}$ and at 4 weeks this difference was $2.5 \mathrm{MPa}$. Differences of compressive strength between $A-1$ and A-2 coarse aggregates for five groups at 1 week and 4 weeks are shown in Table 2.

Table 2. Compressive strength comparison chart of the investigation
\begin{tabular}{|c|c|c|}
\hline Group No. & $\begin{array}{c}\text { Compressive Strength } \\
\text { difference at } 1 \text { week } \\
(\mathrm{MPa})\end{array}$ & $\begin{array}{c}\text { Compressive Strength } \\
\text { difference at 4 weeks } \\
\text { (MPa) }\end{array}$ \\
\hline Group-I & 1.5 & 2.5 \\
\hline Group-II & 1.5 & 2.5 \\
\hline Group-III & 2 & 2.5 \\
\hline Group-IV & 2.5 & 2.5 \\
\hline Group-V & 3 & 3 \\
\hline
\end{tabular}

\section{Conclusion}

To identify the sharp and significant effects on mechanical properties of concrete due to type of crushed aggregate, this study were carried. Study carried on two important properties of concrete- Slum test, which indicates the consistency of concrete and compressive strength, which indicates the bonding of concrete. All through the investigational experiment, different standards like ASTM standards, ACI code, and Indian standards were followed to ensure the accuracy and standard of the experiment. Following key findings were concluded finally:

$\rightarrow$ In general, the slump value for both impact crushed and vertically shafted coarse aggregates decreased moderately for w/c ratio between 0.6 (Group-I) and 0.38 (Group-V).

$\rightarrow$ Concrete sample made with vertically shafted coarse aggregate had higher slum value $(103 \mathrm{~mm})$ compared with impact crushed aggregates (92 mm).

$\rightarrow$ Compressive strength was steadily increased with the decrease of w/c ratio and strength was comparatively high at impact crushed aggregate.

$\rightarrow$ Highest compressive strength (41.5 MPa) was recorded for the samples which was made with impact crushed aggregate maintaining 0.38 w/c ratio.

$\rightarrow$ At the end of the study the difference of compressive strength for both type of aggregates at 1 week and 4 weeks were analysed and it was found that highest strength difference $(3.0 \mathrm{MPa})$ was obtained for w/c ratio 0.38 and it was valid for both 1 week and 4 weeks.

\section{Acknowledgement}

The authors wish to give special thank to R. Tugrul Erdem of Celal Bayar University Engineering Faculty, Department of Civil Engineering, Turkey for his intellectual help for carrying this research. The valuable help from Prof. Dr. Md. Saiful Islam, Prof. Dr. Md. Moinul Islam, Dr. G. M. Sadiqul Islam, Dr. Aysha Akter, Md. Tarequl Islam and Md. Aftabur Rahman of Chittagong University of Engineering \& Technology (CUET) are highly admirable. Material support from Confidence Cement Ltd. and financial support from Prantar Developer's Ltd. as well as technical support from Bangladesh-Sweden Polytechnic Institute, Chittagong and Govt. Polytechnic Institute, Chittagong are highly acknowledged.

\section{References}

[1] Shetty, M.S. (2003 Edition) Concrete Technology: Theory and Practice, S. Chand \& Company Ltd, India.

[2] Midness, S., \& Young, J.F.(1981), Concrete, New York. Prentice Hall.

[3] De Larrard, F. (1999), "Concrete Mixture Proportioning: A Scientific Approach,” London.

[4] Aictin, P.C., High Performance Concrete, E \& FN Spon, London, 1998.

[5] Andersen, P.J. and Johansen, V., "A Guide to Determining the Optimal Gradation of Concrete Aggregates," SHRP-C-334, 1993.

[6] Galloway, J. E. Jr., "Grading, Shape, and Surface Properties," ASTM Special Technical Publication No. 169C, Philadelphia, 1994, pp. 401-410.

[7] Popovics, S. (1994), "The Slump Test Is Useless - Or Is It?" Concrete International, Vol. 16, No. 9, pp. 30-33.

[8] Kosmatka, S. (1994), "Bleeding," ASTM Special Technical Publication No. 169C, Philadelphia, pp. 89-111.

[9] Legg, F.E. Jr. (1998), Aggregates, Chapter 2, Concrete Construction Handbook, ed. Dobrowolski, J. McGraw-Hill, 4th ed.

[10] Durney, T. E. Jr. (1983), "Particle Shape Effects due to Crushing Method and Particle Size,” Thesis, West Virginia University. 
[11] ASTM C 29 Test Method for Bulk Density (“Unit Weight”) and Voids in Aggregate, Philadelphia, PA: American Society for Testing and Materials, 1997.

[12] ASTM C 33 Standard Specification for Concrete Aggregates, Philadelphia, PA: American Society for Testing and Materials, 2003.

[13] ASTM C 109 Standard Test Method for Compressive Strength of Hydraulic Cement Mortars (using 2-in. or [50-mm] Cube Specimens), Philadelphia, PA: American Society for Testing and Materials, 1999.

[14] ASTM C 127, Standard Test Method for Specific Gravity and Absorption of Coarse Aggregate, Philadelphia, PA: American Society for Testing and Materials, 2001.

[15] ASTM C 128, Standard Test Method for Specific Gravity and Absorption of Fine Aggregate, Philadelphia, PA: American Society for Testing and Materials, 2001.

[16] ASTM C 136, Standard Test Method for Sieve Analysis of Fine and Coarse Aggregates, Philadelphia, PA: American Society for Testing and Materials, 2001.

[17] ASTM C 138, Standard Test Method for Unit Weight, Yield, and Air Content (Gravimetric) of Concrete, Philadelphia, PA: American Society for Testing and Materials, 2001.

[18] ASTM C 143, Standard Test Method for Slump of Hydraulic Cement Concrete, Philadelphia, PA: American Society for Testing and Materials, 2000.
[19] ASTM C 157, Standard Test Method for Length Change of Hardened Hydraulic-Cement Mortar and Concrete, Philadelphia, PA: American Society for Testing and Materials, 1999.

[20] ASTM C 187, Standard Test Method for Normal Consistency of Hydraulic Cement, Philadelphia, PA: American Society for Testing and Materials, 1998.

[21] ASTM C 192, Standard Practice for Making and Curing Concrete Tests Specimens in the Laboratory Concrete, Philadelphia, PA: American Society for Testing and Materials, 2000.

[22] ASTM C 204, Standard Test Method for Fineness of Hydraulic Cement by Air Permeability Apparatus, Philadelphia, PA: American Society for Testing and Materials, 2000.

[23] Beaupre, D. and Mindess, S., Rheology of Fresh Concrete: Principles, Measurement, and Applications, Materials Science of Concrete V, ed. Skalny J. and Mindess, S., 1989, pp. 149-190.

[24] Ahmed, E. and El-Kourd, A. (1989) "Properties of Concrete Incorporating Natural and Crushed Stone Very Fine Sand," Materials Journal, American Concrete Institute, Vol. 86, No. 4, pp. 417-424.

[25] Hudson, B.P. (1999), "Concrete Workability with High Fines Content Sands".

[26] Shilstone, J. M, Sr. and Shilstone, J. M., Jr. (2002), “PerformanceBased Concrete Mixtures and Specifications for Today,” Concrete International. 